\title{
INTERNATIONAL HUMANITARIAN LAW AND INTERNATIONALIZED INTERNAL ARMED CONFLICTS
}

\author{
by Dietrich Schindler
}

\section{Introduction}

Internationalized internal armed conflicts have become a common feature of the past decades. In numerous civil wars foreign armed forces have intervened in favour of one or the other party and thereby attempted to influence the outcome of the conflict. Various causes have led to this development. One of them is the increased interdependence of States, as a consequence of which every civil war will affect other States and, conversely, the attitudes of other States may have an impact on the outcome of the civil war, even without any intervention. Another cause can be found in the world's ideological cleavage which divides nations and results in the overlapping of internal and international conflicts. Among further causes we can mention the existence of military blocs and of regional groupings which have an interest in preventing the overthrow of régimes within the bloc and tend to encourage alterations in other blocs. Another factor to be taken into consideration is the prohibition of the use of force in international relations. Whereas in earlier times States waged open wars in order to increase their power, today, due to the prohibition of the use of force, they rather endeavour to achieve the same result by interfering in the internal affairs of other States. Interference in internal conflicts is often a substitute for an international war. The instability of many contemporary régimes, mainly of the Third World, further favours the internationalization of internal conflicts.

The first civil war with foreign interventions on a large scale was the Spanish Civil War in the 1930's. But only since World War II have internationalized civil wars occurred in greater numbers. The war in Vietnam has remained in our memory as the outstanding example. It 
was during that war that the legal issues which are the subject of this paper were discussed for the first time. Apart from Vietnam the following armed conflicts may be mentioned as examples of "mixed" conflicts. Hungary 1956, Congo 1960, Angola 1960-present, Yemen 19621970, Dominican Republic 1965, Chad at various occasions since 1968, Bangladesh (formerly East Pakistan) 1971, Cyprus 1974, Lebanon 1976 -present, Cambodia 1978-present, Afghanistan 1979-present.

The Geneva and the Hague Conventions contain no specific provisions on internationalized civil wars. The 1977 Protocols also fail to regulate this matter although the problem was well-known at the time of the Diplomatic Conference. It is therefore left to the practice of States and to legal doctrine to determine what law is to be applied in an internationalized internal conflict. No easy answers are possible. The subject is full of legal complexities.

At the time of the Vietnam war in the 1960's, two opinions were put forward regarding the applicability of international humanitarian law in internationalized civil wars. According to one, a civil war becomes an international armed conflict by the mere fact of military intervention by foreign powers. International humanitarian law would therefore be applicable in its entirety among all the parties to the conflict, even between the government of the State in which the civil war has broken out and the insurgents. The ICRC suggested this solution when, in June 1965, it requested all parties to the Vietnam conflict to apply the Geneva Conventions of 1949.1 One writer, Meyrowitz, maintained that humanitarian law in its entirety was applicable in the Vietnam war. ${ }^{2}$

According to the other opinion, an internationalized civil war should be broken down into its international and non-international components.

${ }^{1}$ International Review of the Red Cross, 1965, p. 417.

${ }^{2} \mathrm{H}$. Meyrowitz, Le droit de la guerre dans le confit vietnamien, Annuaire français de droit international, 1967, p. 153 and especially pp. 167-169. English translation: "The Law of War in the Vietnamese Confict", in R. A. Falk (ed.), The Vietnam War and International Law, vol. 2, Princeton, 1969, p. 516, esp. pp. 521-533.

3 See D. Bindschedler-Robert, The Law of Armed Conflict, Carnegie Endowment for International Peace, New York, 1971, p. 52-53; M. Bothe, Völkerrechtliche Aspekte des Angola-Konflikts, in Zeitschrift für ausländisches öffentliches Recht und Völkerrecht, 37 (1977) 590-592; J. A. Frowein, Völkerrechtliche Aspekte des VietnamKonfliktes, ibid. 27 (1967) 15-19; H. Meyrowitz (note 2), Annuaire franfais 162, Falk (ed.) 525; A. Rosas, The Legal Status of Prisoners of War, Heisinki, 1976, 283 ff.; D. Schindler, Die Anwendung der Genfer Rotkreuzabkommen seit 1949, in Annuaire suisse de droit international XXII (1965) 93-98; D. Schindler, The different Types of Armed Conflicts according to the Geneva Conventions and Protocols in Recueil des cours de l'Académie de Droit international, 163 (1979) 150-151; R.-J. Wilhelm, Problèmes relatifs a la protection de la personne humaine par le droit international dans les confits armés ne présentant pas un caractere international in Recueil des cours de l'Académie de droit international, 137 (1972) 356-359. 
Two of the relationships are considered as non-international, i.e. the relationships between the insurgents and the established government and between the insurgents and the foreign State which assists the established government. Two other relationships are of an international character. This holds good for conflict between the established government and a State intervening on behalf of the insurgents and for conflict between two States intervening on opposite sides of the civil war. Thus, of the four relationships which can be distinguished in an internationalized internal conflict, two are considered as non-international, and two as international. This concept has the disadvantage that different regulations are applicable depending on which of the parties to the conflict are involved.

At the Conference of Government Experts for the Reaffirmation and Development of International Humanitarian Law in Geneva in 1971 the ICRC proposed the adoption of the following provision: "When, in case of non-international armed conflict, one or the other party, or both, benefits from the assistance of operational armed forces afforded by a third State, the parties to the conflict shall apply the whole of the international humanitarian law applicable in international armed conflicts"."

Had it been accepted, this provision would have conferred the same protection on all victims of an internationalized civil war without regard to the party to which they belonged. But the proposition did not find sufficient support. The majority of the experts thought that such a provision would have encouraged insurgents to call for foreign assistance in order to improve their legal status. ${ }^{5}$

Opposition to this proposal prompted the ICRC to present to the second session of the Conference of Experts, convened in 1972, an amended draft combining the two concepts mentioned above. ${ }^{6}$ According to it the humanitarian rules in their entirety would have been applicable if the established government or both parties to the civil war were assisted by foreign States, but not if the insurgents alone received outside assistance. But this proposal also failed to win the approval of the experts, who felt that it still too strongly favoured the insurgents. The ICRC therefore abandoned its efforts to insert provisions on internationalized civil war in the drafts of the two protocols. At the Diplomatic Conference itself, the issue of internationalized civil war was not raised

\footnotetext{
- International Committee of the Red Cross, Report on the Work of the Conference of Government Experts, 1971, para. 284.

Ibid. para. 301.

- International Committee of the Red Cross, Report on the Work of the Conference of Government Experts, 1972, vol. I, para. $2.332 \mathrm{ff}$.
} 
at all. The Diplomatic Conference consolidated the traditional dichotomy between international and non-international conflicts. Significantly, the Norwegian proposal for a single protocol applicable in both international and non-international conflicts attracted no support.? Therefore today we have to proceed from the standpoint that in internationalized civil war a distinction has to be made between its international and non-international components.

The following remarks will deal first with the four different relationships which can be distinguished in internationalized internal armed conflicts. Thereafter the particular situation arising from the forcible installation of a new government by a foreign State will be discussed. The question of the legality of foreign intervention in civil wars will be left aside as it has no bearing on the applicability of international humanitarian law.

\section{The four different relationships in internationalized internal armed conflicts}

Let us start with the two relationships which are clearly international. The first one is the one between two foreign States intervening on behalf of the two parties to a civil war. ${ }^{8}$ If their armed forces engage in hostilities with one another, or if one of these States encroaches upon the territory of the other, international humanitarian law in its entirety is applicable between them. All the treaties on armed conflicts to which the relevant States are parties have to be applied, as well as the customary rules of the laws of war.

The second relationship, between the foreign State which assists the insurgents, on the one hand, and the established government, on the other hand, also indisputedly falls within the scope of rules relating to international armed conflicts, since it involves two subjects of international law.' A special problem arises when the foreign State which assists the insurgents takes combatants of the established government prisoner and hands them over to the insurgents. Art. 12 of the Third

${ }^{7}$ Ibid. 1971, para. 133; 1972, vol. I, para. $0.14 \mathrm{ff}$. and 2.71. Official Records of the Diplomatic Conference on the Reaffirmation and Development of International Humanitarian Law Applicable in Armed Conflicts, Geneva 1974-1977, p. 203, 217.

In the Vietnam war the relationship between the United States and North Vietnam was considered as falling into this category.

- In the Vietnam war the relationship between North and South Vietnam was considered as falling into this category. 
Geneva Convention provides that prisoners of war may be transferred only from a detaining Power to a Power which is a party to the Convention and only after the detaining Power has satisfied itself that the Power in question is willing and able to apply the Convention. Therefore, the combatants of the established government who have been taken prisoner may not be transferred to the insurgents who are not and cannot become a party to the Conventions as long as they are isurgents. A corresponding provision in the Fourth Geneva Convention (Article 45) prohibits the transfer of enemy civilians who are on the territory of the intervening State to a Power which is not a party to that Convention. However, if the insurgents are victorious and take over the government in their State, they will themselves become the representatives of a party to the Geneva Conventions. Thereupon, prisoners of war and civilians may be transferred to them.

The third relationship, between the established government and the insurgents, is one of a non-international armed conflict in which only Art. 3 of the four Geneva Conventions and Protocol II-if its conditions are met-are to be applied. ${ }^{10}$ There are, however, several possibilities to make international humanitarian law in its entirety applicable between these two parties:

1. Article 3 calls upon the parties to a non-international conflict to bring into force, by means of special agreements, all or part of the other provisions of the Conventions. They may do so also by unilateral declarations. In the Vietnam war, the United States and South Vietnam declared their readiness to apply international humanitarian law to the Vietcong to a further extent than Article 3 stipulates.

2. According to traditional international law the established government may recognize the insurgents as belligerents. If it does so the laws of war become applicable in their entirety between it and the insurgents.11 However, such a recognition has not happened for several decades so that it has lost its practical importance. Nevertheless, it has been argued that acceptance of foreign military aid by the established government constitutes an implicit recognition of belligerency. This view was at

${ }^{10}$ In the Vietnam war the relationship between the government of South Vietnam and the National Liberation Front of South Vietnam (NLF, Vietcong) was considered as falling into this category.

11 See D. Schindler, State of War, Belligerency, Armed Conflict, in A. Cassese (ed.), The New Humanitarian Law of Armed Conflict, Naples, 1979, 3, 5-6; Wilhelm (note 3) 326-331; Ch. Zorgbibe, La guerre civile, Paris, 1975, 36 ff., 71 ff.; Zorgbibe, Sources of the Recognition of belligerent status in International Review of the Red Cross, March, 1977 , p. 111. 
the origin of the proposal made by the ICRC in 1971, mentioned above. ${ }^{19}$ Yet, after the negative reaction of the government experts in 1971 and 1972 this conception can hardly be upheld.

3. If the insurgents are assisted by an outside State they could be regarded as an organized resistance movement belonging to that State. Article 4, A, 2 of the Third Geneva Convention (corresponding to Article 13, 2 of the First and of the Second Convention) provides that members of "organized resistance movements, belonging to a Party to the conflict" shall be prisoners of war if they have fallen into the power of the enemy. International humanitarian law would have to be applied in its entirety to them. ${ }^{13}$ In the Vietnam conflict Meyrowitz argued that the Vietcong could be regarded as a resistance movement belonging to North Vietnam. ${ }^{14}$ Insurgents will, however, hardly make use of this possibility since they wish to prove their independence and will therefore avoid being considered as belonging to a foreign State. While the word "belonging" in the 1949 Conventions does not allude to a bond of dependence in a legal sense, but rather to a de facto connection, Article 43 of Protocol I of 1977 requires that all armed forces, groups or units of a Party to a conflict "are under a command responsible to that Party for the conduct of its subordinates". That implies subordination.

4. Meyrowitz, in 1967, brought forward a legal argument to affirm the international character of the relationship between the established government and the insurgents and between the State intervening on the side of the established government and the insurgents. He held that due to the American assistance to South Vietnam the centre of the military and political decisions in this war had shifted from Saigon to Washington. ${ }^{15}$ Under these circumstances, in his opinion, to construe the relationship between Saigon and the Vietcong and that between the United States and the Vietcong as a civil war was to ignore realities. Still, Meyrowitz did not pursue this reasoning to extremes since he

12 See Reaffirmation and Development of the Laws and Customs Applicable in Armed Conflicts, a report submitted by the ICRC to the Twenty-first International Red Cross Conference at Istanbul, 1969, p. 116; and Conference of Government Experts on the Reaffirmation and Development of International Humanitarian Law Applicable in Armed Conflicts, ICRC, Geneva, 1971, Documentation submitted by the ICRC, $\mathrm{V}$ pp. 19-21.

${ }^{18}$ This would, however, not prevent the established government from trying such prisoners of war for high treason or similar crimes (Article 85 of the Third Geneva Convention).

14 Meyrowitz (note 2), Annuaire franfais 173, Falk (ed.) p. 538.

${ }^{15}$ Meyrowitz (note 2), Annuaire francais 167, Falk (ed.) p. 531. 
correctly held that the Vietcong was not bound by the Geneva Conventions.

In practice, only resort to the first possibility seems likely.

The fourth relationship, between insurgents and a State assisting the established government is also considered to be of a non-international nature. ${ }^{16}$ This is explained by the fact that insurgents have no status in international law. In principle, the same possibilities exist for application of international humanitarian law in its entirety as those already mentioned for the relationship between the established government and the insurgents:

1. The parties to the armed conflict may conclude the agreements provided for in Article 3 of the Geneva Conventions or issue specific declarations that they will apply all or part of the other provisions of the Conventions.

2. Like the established government, the intervening State may recognize the insurgents as belligerents and thereby make the laws of war in their entirety applicable in its relations with the insurgents.

3. The insurgents may be regarded as a resistance movement belonging to the State which assists them.

Insofar as the relations between the outside State assisting the established government and the insurgents are concerned it must be emphasized that the outside State would conform with the spirit of the Conventions and Protocol $I$ if it applied the humanitarian law in its entirety, for a State which intervenes on the territory of another State exercises sovereign power over citizens of the other State, even if it does so upon the invitation or with the permission of the established government. This relationship-which was not examined at the Conferences of 1949 and $1977-$ is therefore to be considered as international to a much higher degree than the relationship between the established government and the insurgents. As has been mentioned, the United States and South Vietnam declared themselves ready in the Vietnam war to apply the Conventions, at least in part, also to the Vietcong.

\section{Forcible installation of a new government through the intervention of a foreign State}

Special problems arise if one State intervenes in another State without the consent of the government of that State in order to install

\footnotetext{
${ }^{18}$ In the Vietnam war the relationship between the Vietcong and the United States was considered as falling into this category.
} 
a new government which, in turn, gives its assent to the presence of the armed forces of the intervening State. Such an intervention is conceivable without a civil war being fought in the State where the intervention takes place.

Nonetheless, as a result of the intervention an armed conflict may break out on the territory of this State. In such a conflict, the two parties opposing one another can be the intervening State and the government installed by it, on one side, and the displaced government, or a new one which has taken its place, or even mere resistance movements, on the other side. For an example we may refer to the German invasion of Norway in 1940 which was accompanied by the installation of the Quisling Government by Germany. We would have to imagine that the invasion did not actually occur in connexion with a major war but as an isolated military encroachment in order to install in the foreign State a government acceptable to the intervening State. In such a case three different situations may arise, each differently affecting the applicability of international humanitarian law.

Let us assume first the situation in which the government had been displaced and the government newly installed had established itself without the occurrence of armed hostilities. In such a case, the rules of belligerent occupation are to be applied as long as the armed forces of the foreign State remain in the territory of the other (Article 2, para. 2, of the Geneva Conventions). Article 47 of the Fourth Geneva Convention states that changes in the government or in the institutions of the occupied State which are introduced as the result of the occupation shall not affect the rights of protected persons. Nevertheless, in such a situation the status of belligerent occupation cannot continue infinitely. If the new government has successfully installed itself and if it is also predominantly recognized by foreign States, we must assume that, in accordance with the principle of effectiveness and owing to the express or implicit recognition of the situation by other Powers, the conditions for the application of the Geneva Conventions will no longer obtain, even if the armed forces of the foreign State are still present.

In our second hypothesis the previous government has not disappeared but is continuing to offer resistance, perhaps from the bush or a foreign country. ${ }^{17}$ Such a government is engaged in an international armed conflict with the intervening State, for it continues to assume the position of a government, though of course without being recognized as such by the intervening State. According to Article 13 of the First

${ }^{17}$ It has been argued that such has been the case in Cambodia since 1978. 
and Second Geneva Conventions, Article 4 of the Third Geneva Convention and Article 43 of Protocol I, the members of the armed forces of a non-recognized government are to be treated as combatants. Between the newly installed government and the previous government there exists a non-international conflict. On the whole, we may say that the position of the old government is the same as that of the established government in a civil war, whereas the position of the newly installed government is like that of insurgents. Of course, the situation may change, if it turns out that the old government no longer has any possibility of obtaining power, and if most of the other States have recognized the new government installed by the intervening State. In such a case the government installed by the intervening State would occupy the position of the established government, whereas the old government would be pushed into the position of insurgents.

Let us consider a third situation lying between the two previously mentioned, i.e. One in which a State has succeeded by means of a surprise move to install a new government in another State without the occurrence of any armed fighting, but gradually resistance movements form and take up the fight against the intervening State and the government it has installed. ${ }^{18}$ In such a case, the regulations on belligerent occupation would continue to be applicable insofar as the intervening State comes into contact with the civilian population of the occupied State. The international law status of the resistance movements and any regular armed forces of the occupied State which are taking up the fight will depend on whether they are fighting under the command of a government or an authority which can be ascribed to the occupied State. If, following the example of General de Gaulle in the Second World War, a new government of the occupied State were formed to take up the fight against the occupying Power, and against the government installed by it, this new government, not recognized by the opponent, would have the status of a government within the meaning of Article 13 of the first two Geneva Conventions, Article 4 of the Third Geneva Convention and Art. 43 of Protocol I. The conflict between the occupying Power and the armed forces of the new government would, therefore, be an international conflict.

On the other hand, the conflict between the government installed by the occupying Power and the newly formed government would be of a non-international character. If, however, the resistance movements fight without being placed under a political command, they cannot be

${ }^{18}$ It has been argued that this has been the case in Afghanistan since 1979. 
regarded as the armed forces of the occupied State, since no authority will take responsibility for them. The intervening State and the government installed by it would have to apply to them only the rules on noninternational conflicts.

\author{
Dietrich Schindler \\ Professor at Zürich University \\ Member of the ICRC
}

